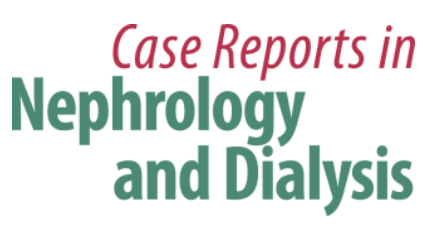

\title{
Characteristics of Intravascular Large B-Cell Lymphoma Limited to the Glomerular Capillaries: A Case Report
}

\author{
Jumpei Hasegawa ${ }^{a}$ e Junichi Hoshino ${ }^{a}$ Tatsuya Suwabe $^{a}$ \\ Noriko Hayami ${ }^{a}$ Keiichi Sumida ${ }^{a}$ Koki Mise $^{a}$ Toshiharu Ueno $^{a}$ \\ Naoki Sawa ${ }^{a}$ Atsushi Wake ${ }^{b}$ Kenichi Ohashic Takeshi Fujii ${ }^{c}$ \\ Kazuho Honda $^{f}$ Kenmei Takaichi ${ }^{a, d}$ Yoshifumi Ubara ${ }^{a, d}$ \\ ${ }^{a}$ Nephrology Center, and Departments of ${ }^{b}$ Hematology and ${ }^{c}$ Pathology, Toranomon \\ Hospital, ${ }^{d}$ Okinaka Memorial Institute for Medical Research, ${ }^{e}$ Department of Nephrology, \\ Ohkubo Hospital, and 'Department of Pathology, Tokyo Women's Medical University, \\ Tokyo, Japan
}

\section{Key Words}

Intravascular large B-cell lymphoma, kidney-limited · Glomerular capillary · Kidney biopsy

\begin{abstract}
A 65-year-old woman was admitted to our hospital for the evaluation of rapidly progressive renal dysfunction with serum creatinine of $2.7 \mathrm{mg} / \mathrm{dl}$ and urinary protein of $1.5 \mathrm{~g}$ daily. Creactive protein (CRP) was $0.1 \mathrm{mg} / \mathrm{dl}$. Kidney-limited intravascular large B-cell lymphoma (IVL) localized to the glomerular capillaries was diagnosed because the intraglomerular cells were positive for CD20 and CD79a, while there was no positivity in the extraglomerular kidney and extrarenal organs. Treatment with rituximab, cyclophosphamide, hydroxydaunomycin, vincristine, and prednisolone was started, and the patient has since been doing well. When IVL is limited to the intraglomerular capillaries, CRP may not be elevated.
\end{abstract}

(c) 2015 S. Karger AG, Basel 


\section{Case Reports in \\ Nephrology \\ and Dialysis}

\begin{tabular}{l|l}
\hline \multicolumn{2}{l}{ Case Rep Nephrol Dial 2015;5:173-179 } \\
\hline DOI: 10.1159/000437296 & $\begin{array}{l}\text { ○ 2015 S. Karger AG, Basel } \\
\text { www.karger.com/cnd }\end{array}$ \\
\hline
\end{tabular}

Hasegawa et al.: Characteristics of Intravascular Large B-Cell Lymphoma Limited to the Glomerular Capillaries: A Case Report

\section{Introduction}

According to the current WHO classification, intravascular large B-cell lymphoma (IVL) is a rare type of non-Hodgkin's lymphoma characterized by the selective growth of tumor cells within the lumens of the small vessels in various organs, including the kidney [1, 2]. In 2003, Tornroth et al. [3] reviewed renal involvement by IVL based upon previous reports and their own cases and concluded that this disease can be divided into an intraglomerular type and a type with tubulointerstitial invasion. They stated that the latter type features diffuse invasion of lymphoma cells into the tubulointerstitial region. In 2007, Sawa et al. [4] reported the first case of tubulointerstitial IVL limited to the peritubular capillaries. In 2009, Kameoka et al. [5] reported that kidney-limited IVL was very rare. In fact, the majority of patients who have been reported with renal involvement by IVL also had extrarenal lesions in addition to renal ones.

We encountered a 65-year-old Japanese woman with kidney-limited IVL localized to the glomerular capillaries in whom C-reactive protein (CRP) was negative. Here, we review the relation between kidney-limited IVL and CRP based on this case and previous reports.

\section{Case Report}

A 65-year-old Japanese woman was admitted to our hospital for the evaluation of rapidly progressive renal dysfunction. At the age of 60 years (April 2000), hypertension was detected, and treatment with amlodipine was started. Subsequently, proteinuria $(41 \mathrm{mg} / \mathrm{dl})$ was noted, and serum creatinine (Cre) was $0.94 \mathrm{mg} / \mathrm{dl}$. On September 3, 2005, edema of the bilateral lower extremities was noted with exacerbation of hypertension $(200 / 110 \mathrm{~mm} \mathrm{Hg})$. She was admitted to hospital 2 days later on September 5.

On admission, her height was $154 \mathrm{~cm}$, her weight was $48.2 \mathrm{~kg}$, her blood pressure was $152 / 92 \mathrm{~mm} \mathrm{Hg}$, and her temperature was $35.9^{\circ} \mathrm{C}$. No enlarged lymph nodes were palpable. Inspiratory and expiratory sounds were normal on auscultation. Both neurological examination and cutaneous examination revealed no abnormalities. There was pitting edema of the bilateral lower extremities. Laboratory findings are shown in table 1. Urea nitrogen was 41 $\mathrm{mg} / \mathrm{dl}$, and Cre was $2.7 \mathrm{mg} / \mathrm{dl}$. CRP was $0.1 \mathrm{mg} / \mathrm{dl}$, and the erythrocyte sedimentation rate was $53 \mathrm{~mm} / \mathrm{h}$. Soluble interleukin-2 receptor was elevated to 1,680 U/ml (normal range: 250-590). Urine sediment contained 6-10 erythrocytes per high-power field. Examination of a 24-hour urine specimen revealed excretion of $1.51 \mathrm{~g}$ of protein.

Computed tomography showed a normal liver and spleen with no lymphadenopathy. Both kidneys were small with a long axis of $9 \mathrm{~cm}$ bilaterally (fig. 1a). Echogenicity of the renal cortex was increased on ultrasonography (fig. 1b). Scintigraphy with ${ }^{67} \mathrm{Ga}$-citrate only showed positive uptake by the kidneys.

\section{Renal Biopsy Findings}

Renal biopsy was performed. Light microscopy of a specimen containing 12 glomeruli revealed global sclerosis in 2 . There was mild fibrosis and atrophy, as well as very slight cellular infiltration, in the tubulointerstitial region (fig. 2a). Six of the 12 glomeruli were enlarged (fig. 2b), and the glomerular capillaries were filled with large atypical cells that had atypical nucleoi (fig. 2c). There was no increase in the mesangial matrix or mesangial cell proliferation. Immunohistochemical staining detected atypical large lymphoid cells in the glomerular capillaries that were positive for CD20 (fig. 3a) and CD79a (fig. 3b), but negative for CD3 (fig. 3c) and CD10. Lymphocytes in the tubulointerstitium were positive for CD3, but negative for CD20 and CD79a. Immunostaining was negative for IgG, IgA, IgM, and C3. Elec- 


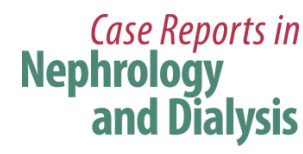

\begin{tabular}{l|l}
\hline Case Rep Nephrol Dial 2015;5:173-179 \\
\hline DOI: $10.1159 / 000437296$ & $\begin{array}{l}\text { C 2015 S. Karger AG, Basel } \\
\text { www.karger.com/cnd }\end{array}$ \\
\hline
\end{tabular}

Hasegawa et al.: Characteristics of Intravascular Large B-Cell Lymphoma Limited to the Glomerular Capillaries: A Case Report

tron microscopy revealed numerous atypical cells with large nuclei, large nucleoli, masses of chromatin in the outer zones of the nuclei, and an abundance of endoplasmic reticulum (fig. 4). No deposits of immunoglobulins/complement components were detected. Bone marrow aspiration and flow cytometric analysis did not detect any abnormal cell populations. Endoscopy of the upper and lower gastrointestinal tract showed no abnormal findings. Based on these findings, kidney-limited IVL localized to the glomerular capillaries was diagnosed.

\section{Clinical Course}

Treatment with CHOP regimen, including cyclophosphamide of $1,000 \mathrm{mg}\left(750 \mathrm{mg} / \mathrm{m}^{2}\right)$, hydroxyl doxorubicin of $70 \mathrm{mg}\left(50 \mathrm{mg} / \mathrm{m}^{2}\right)$, and oncovin (vincristine) of $2 \mathrm{mg}\left(1.4 \mathrm{mg} / \mathrm{m}^{2}\right)$ intravenously for 1 day and prednisolone of $100 \mathrm{mg}$ orally daily for 5 days was started. Constipation-related ileus occurred after the first cycle of this therapy. This symptom was considered due to motor neurological dysfunction, probably related to an overdosage of vincristine. Thus, at the second cycle, this drug was switched to vindesine of $3 \mathrm{mg}$, and rituximab of $600 \mathrm{mg}$ was added (as R-CHOP therapy), and a total of 6 cycles were performed at 4-week intervals. Her serum creatinine decreased from 3.2 to $1.4 \mathrm{mg} / \mathrm{dl}$, and urinary protein became negative immediately after the end of the R-CHOP therapy. Two months after completing 6 courses of therapy, relapse occurred with an increase in lactate dehydrogenase. She then received 3 courses of rituximab of $600 \mathrm{mg}$, cyclophosphamide of $850 \mathrm{mg}$, cytosine arabinoside of 1,400 mg for 2 days, etoposide of $70 \mathrm{mg}$ for 3 days, and dexamethasone of $40 \mathrm{mg}$ for 3 days (R-CHASE therapy) as salvage chemotherapy, and complete remission was achieved. After 108 months, she is doing well with a Cre of $1.21 \mathrm{mg} / \mathrm{dl}$, daily urinary protein excretion of $0.21 \mathrm{~g}$, CRP of $0.01 \mathrm{mg} / \mathrm{dl}$, and lactate dehydrogenase of $197 \mathrm{IU} / \mathrm{l}$.

\section{Discussion}

IVL was first reported in 1959 by Pfleger and Tappeiner [6] as 'angioendotheliomatosis proliferans systemisata'. According to the latest WHO classification, IVL is a rare type of extranodal diffuse large B-cell lymphoma [7]. Patients with IVL usually have no lymphadenopathy, and tumor cells involve the small vessels of many organs, such as the bone marrow, central nervous system, skin, lungs, liver, kidneys, and intestinal tract [8]. IVL is very aggressive, and the prognosis is usually extremely poor [9], but chemotherapy including a chimeric anti-CD20 monoclonal antibody (most commonly rituximab) has been reported to achieve a relatively good response [10], and autologous stem cell transplantation can also lead to good outcomes [11].

The serum level of CRP is known to be a nonspecific simple test that may become positive for numerous inflammatory conditions. However, this test can be a useful prognostic marker for non-Hodgkin's lymphoma and Hodgkin's lymphoma associated with interleukin6 overproduction [12]. We reviewed reports about CRP in patients with IVL and found the following. Tornroth et al. [3] reported 5 patients with diffuse bilateral renal lymphoma. All 5 patients showed elevation of CRP. Among them, 2 patients had bone marrow involvement, and 1 patient showed skin lesions. One patient had the interstitial type of IVL sparing the glomeruli. Renal biopsy showed the intraglomerular type in 1 patient, but autopsy demonstrated minute lymphoma aggregates in the peritubular capillaries as well as intraglomerular tumor cells. Wood et al. [13] reported a case of IVL of the intraglomerular type. CRP was $16.2 \mathrm{mg} / \mathrm{dl}$, and only occasional interstitial tumor cells were detected. Subsequently, involvement of the lymph nodes, liver, spleen, lungs, and bone marrow became apparent in this patient. Kameoka et al. [5] reported a 40-year-old Japanese woman with intraglomerular IVL. CRP was normal at $0.02 \mathrm{mg} / \mathrm{dl}$, and extrarenal involvement was not detected. 


\section{Case Reports in \\ Nephrology \\ and Dialysis}

\begin{tabular}{l|l}
\hline \multicolumn{2}{l}{ Case Rep Nephrol Dial 2015;5:173-179 } \\
\hline DOI: 10.1159/000437296 & $\begin{array}{l}\text { ○ 2015 S. Karger AG, Basel } \\
\text { www.karger.com/cnd }\end{array}$ \\
\hline
\end{tabular}

Hasegawa et al.: Characteristics of Intravascular Large B-Cell Lymphoma Limited to the Glomerular Capillaries: A Case Report

In conclusion, we managed a patient with intraglomerular IVL limited to the intraglomerular capillaries, without extraglomerular or extrarenal involvement. CRP was not elevated. When IVL is confined to the intraglomerular capillaries, CRP may be normal. However, elevation of CRP may occur in patients who have renal IVL with interstitial involvement or extrarenal lesions. Because CRP is a systemic inflammatory marker that indicates overproduction of interleukin-6, elevation of CRP may be involved in the process by which the disease progresses from the intraglomerular capillaries to the systemic vessels [12].

\section{Acknowledgments}

This study was funded by the Okinaka Memorial Institute for Medical Research.

\section{Disclosure Statement}

The authors report no conflicts of interest.

\section{References}

1 Ponzoni M, Ferreri AJ, Campo E, Facchetti F, Mazzucchelli L, Yoshino T, Murase T, Pileri SA, Doglioni C, Zucca E, Cavalli F, Nakamura S: Definition, diagnosis, and management of intravascular large B-cell lymphoma: proposals and perspectives from an international consensus meeting. J Clin Oncol 2007;25:3168-3173.

-2 Murase T, Yamaguchi M, Suzuki R, Okamoto M, Sato Y, Tamaru J, Kojima M, Miura I, Mori N, Yoshino T, Nakamura S: Intravascular large B-cell lymphoma (IVLBCL): a clinicopathologic study of 96 cases with special reference to the immunophenotypic heterogeneity of CD5. Blood 2007;109:478-485.

-3 Törnroth T, Heiro M, Marcussen N, Franssila K: Lymphomas diagnosed by percutaneous kidney biopsy. Am J Kidney Dis 2003;42:960-971.

4 Sawa N, Ubara Y, Katori H, Hoshino J, Suwabe T, Tagami T, Takemoto F, Miyakoshi S, Taniguchi S, Ohashi K, Takaichi K: Renal intravascular large B-cell lymphoma localized only within peritubular capillaries. Report of a case. Intern Med 2007;46:657-662.

-5 Kameoka Y, Takahashi N, Komatsuda A, Tagawa H, Hamai K, Hirokawa M, Wakui H, Ichinohasama R, Sawada K: Kidney-limited intravascular large B cell lymphoma: a distinct variant of IVLBCL? Int J Hematol 2009;89:533-537.

6 Pfleger L, Tappeiner J: On the recognition of systematized endotheliomatosis of the cutaneous blood vessels (reticuloendotheliosis?) (in German). Hautarzt 1959;10:359-363.

7 Gatter KC, Warnke RA: Intravascular large B-cell lymphoma; in Jaffe ES, Harris NL, Stein H, Vardiman JW (eds): World Health Organization Classification of Tumours: Pathology and Genetics of Tumors of Haematopoietic and Lymphoid Tissues. Lyon, IARC Press, 2001, pp 177-178.

-8 Ferreri AJ, Campo E, Seymour JF, Willemze R, Ilariucci F, Ambrosetti A, Zucca E, Rossi G, López-Guillermo A, Pavlovsky MA, Geerts ML, Candoni A, Lestani M, Asioli S, Milani M, Piris MA, Pileri S, Facchetti F, Cavalli F, Ponzoni M; International Extranodal Lymphoma Study Group (IELSG): Intravascular lymphoma: clinical presentation, natural history, management and prognostic factors in a series of 38 cases, with special emphasis on the 'cutaneous variant'. Br J Haematol 2004;127:173-183.

-9 DiGiuseppe JA, Nelson WG, Seifter EJ, Boitnott JK, Mann RB: Intravascular lymphomatosis: a clinicopathologic study of 10 cases and assessment of response to chemotherapy. J Clin Oncol 1994;12:2573-2579.

10 Ferreri AJ, Dognini GP, Govi S, Crocchiolo R, Bouzani M, Bollinger CR, D’Incan M, Delaporte E, Hamadani M, Jardin F, Martusewicz-Boros M, Montanari M, Szomor A, Zucca E, Cavalli F, Ponzoni M: Can rituximab change the usually dismal prognosis of patients with intravascular large B-cell lymphoma? J Clin Oncol 2008;26:5134-5136.

11 Sawamoto A, Narimatsu H, Suzuki T, Kurahashi S, Sugimoto T, Sugiura I: Long-term remission after autologous peripheral blood stem cell transplantation for relapsed intravascular lymphoma. Bone Marrow Transplant 2006;37:233-234.

12 Legouffe E, Rodriguez C, Picot MC, Richard B, Klein B, Rossi JF, Commes T: C-reactive protein serum level is a valuable and simple prognostic marker in non Hodgkin's lymphoma. Leuk Lymphoma 1998;31:351-357. Wood SM, Boyd SM, Taylor JE, Savill J: A case of non-Hodgkin lymphoma presenting primarily with renal failure. Nephrol Dial Transplant 1996;11:535-536. 
Case Reports in

Nephrology

and Dialysis

\begin{tabular}{l|l}
\hline \multicolumn{2}{l|}{ Case Rep Nephrol Dial 2015;5:173-179 } \\
\hline DOI: $10.1159 / 000437296$ & $\begin{array}{l}\text { C } 2015 \text { S. Karger AG, Basel } \\
\text { www.karger.com/cnd }\end{array}$ \\
\hline
\end{tabular}

Hasegawa et al.: Characteristics of Intravascular Large B-Cell Lymphoma Limited to the Glomerular Capillaries: A Case Report

Table 1. Laboratory data of the present case on admission to our hospital

\begin{tabular}{|c|c|c|}
\hline & Values & Normal range \\
\hline \multicolumn{3}{|l|}{ Urinalysis } \\
\hline Protein, g/day & 1.51 & 0.0 \\
\hline Sugar & negative & negative \\
\hline Erythrocytes (n/high-power field) & $6-10$ & $<1$ \\
\hline$\beta_{2}$-Microglobulin, $\mu \mathrm{g} /$ day & 2,391 & $<400$ \\
\hline $\mathrm{N}$-acetyl- $\beta$-D-glucosaminidase, IU/day & 18 & $<90$ \\
\hline Bence-Jones proteinuria & negative & negative \\
\hline \multicolumn{3}{|l|}{ Blood count } \\
\hline White blood cells, $\mathrm{n} / \mu \mathrm{l}$ & 4,100 & $3,300-8,800$ \\
\hline Red blood cells, $\mathrm{n} / \mu \mathrm{l}$ & $353 \times 10^{4}$ & $430-550$ \\
\hline Hemoglobin, g/dl & 11.0 & $13.5-17.0$ \\
\hline Hematocrit, \% & 33.1 & $39.7-51.0$ \\
\hline Platelets, $\mathrm{n} / \mu \mathrm{l}$ & $32.5 \times 10^{4}$ & $13.0-35.0$ \\
\hline Erythrocyte sedimentation rate, $\mathrm{mm} / \mathrm{h}$ & 53 & $<10$ \\
\hline \multicolumn{3}{|l|}{ Serum chemistry } \\
\hline Total bilirubin, mg/dl & 0.5 & $0.3-1.1$ \\
\hline Aspartate aminotransferase, IU/l & 22 & $13-33$ \\
\hline Alanine aminotransferase, IU/l & 11 & $8-42$ \\
\hline Lactate dehydrogenase, IU/l & 362 & $103-109$ \\
\hline Alkaline phosphatase, IU/l & 185 & $117-350$ \\
\hline$\gamma$-Glutamyl transpeptidase, IU/l & 19 & $9-109$ \\
\hline $\mathrm{UN}, \mathrm{mg} / \mathrm{dl}$ & 41.0 & $8-22$ \\
\hline $\mathrm{Cr}, \mathrm{mg} / \mathrm{dl}$ & 2.7 & $0.60-1.00$ \\
\hline $\mathrm{UA}, \mathrm{mg} / \mathrm{dl}$ & 7.0 & $3.6-7.0$ \\
\hline $\mathrm{Na}, \mathrm{mEq} / \mathrm{l}$ & 141 & $135-149$ \\
\hline $\mathrm{K}, \mathrm{mEq} / \mathrm{l}$ & 4.6 & $3.5-4.9$ \\
\hline $\mathrm{Cl}, \mathrm{mEq} / \mathrm{l}$ & 105 & $96-108$ \\
\hline $\mathrm{TP}, \mathrm{g} / \mathrm{dl}$ & 7.7 & $6.7-8.3$ \\
\hline $\mathrm{Alb}, \mathrm{g} / \mathrm{dl}$ & 3.9 & $4.0-5.0$ \\
\hline T-chol, mg/dl & 140 & $128-219$ \\
\hline Glucose, $\mathrm{mg} / \mathrm{dl}$ & 88 & $69-109$ \\
\hline $\mathrm{HbA1c}, \%$ & 4.7 & $4.3-5.8$ \\
\hline \multicolumn{3}{|l|}{ Immunological findings } \\
\hline $\mathrm{CRP}, \mathrm{mg} / \mathrm{dl}$ & 0.1 & $0.0-0.3$ \\
\hline $\mathrm{IgG}, \mathrm{mg} / \mathrm{dl}$ & 1,428 & $870-1,700$ \\
\hline $\mathrm{IgA}, \mathrm{mg} / \mathrm{dl}$ & 145 & $110-410$ \\
\hline IgM, mg/dl & 95 & $33-190$ \\
\hline $\mathrm{CH} 50, \mathrm{U} / \mathrm{ml}$ & 57 & $32-47$ \\
\hline $\mathrm{C} 3, \mathrm{mg} / \mathrm{dl}$ & 115 & $65-135$ \\
\hline $\mathrm{C} 4, \mathrm{mg} / \mathrm{dl}$ & 47 & $13-35$ \\
\hline Antinuclear antibody & negative & negative \\
\hline Anti-ds-DNA antibody, IU/ml & $<12$ & $<12.0$ \\
\hline MPO-ANCA, EU & $<10$ & $<2$ \\
\hline PR3-ANCA, EU & $<10$ & $<10$ \\
\hline Anti-GBM Ab, EU & $<10$ & $<10$ \\
\hline Soluble interleukin-2 receptor, IU/l & 1,680 & $250-590$ \\
\hline
\end{tabular}




\section{Case Reports in \\ Nephrology \\ and Dialysis}

\begin{tabular}{l|l}
\hline \multicolumn{2}{l}{ Case Rep Nephrol Dial 2015;5:173-179 } \\
\hline DOI: 10.1159/000437296 & $\begin{array}{l}\text { ○ 2015 S. Karger AG, Basel } \\
\text { www.karger.com/cnd }\end{array}$ \\
\hline
\end{tabular}

Hasegawa et al.: Characteristics of Intravascular Large B-Cell Lymphoma Limited to the Glomerular Capillaries: A Case Report
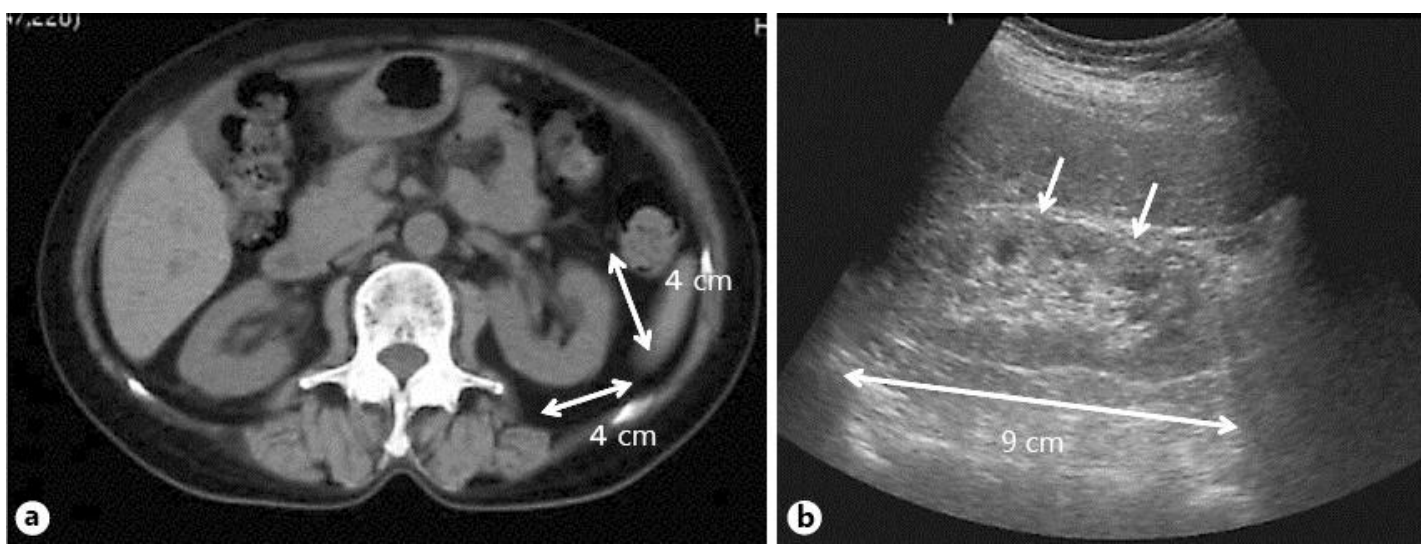

Fig. 1. Imaging findings. a Computed tomography showed a decrease in kidney size with a long axis of $9 \mathrm{~cm}$ and a short axis of $4 \times 4 \mathrm{~cm}$ bilaterally. b Ultrasonography demonstrated increased echogenicity (arrows) of the renal cortex.
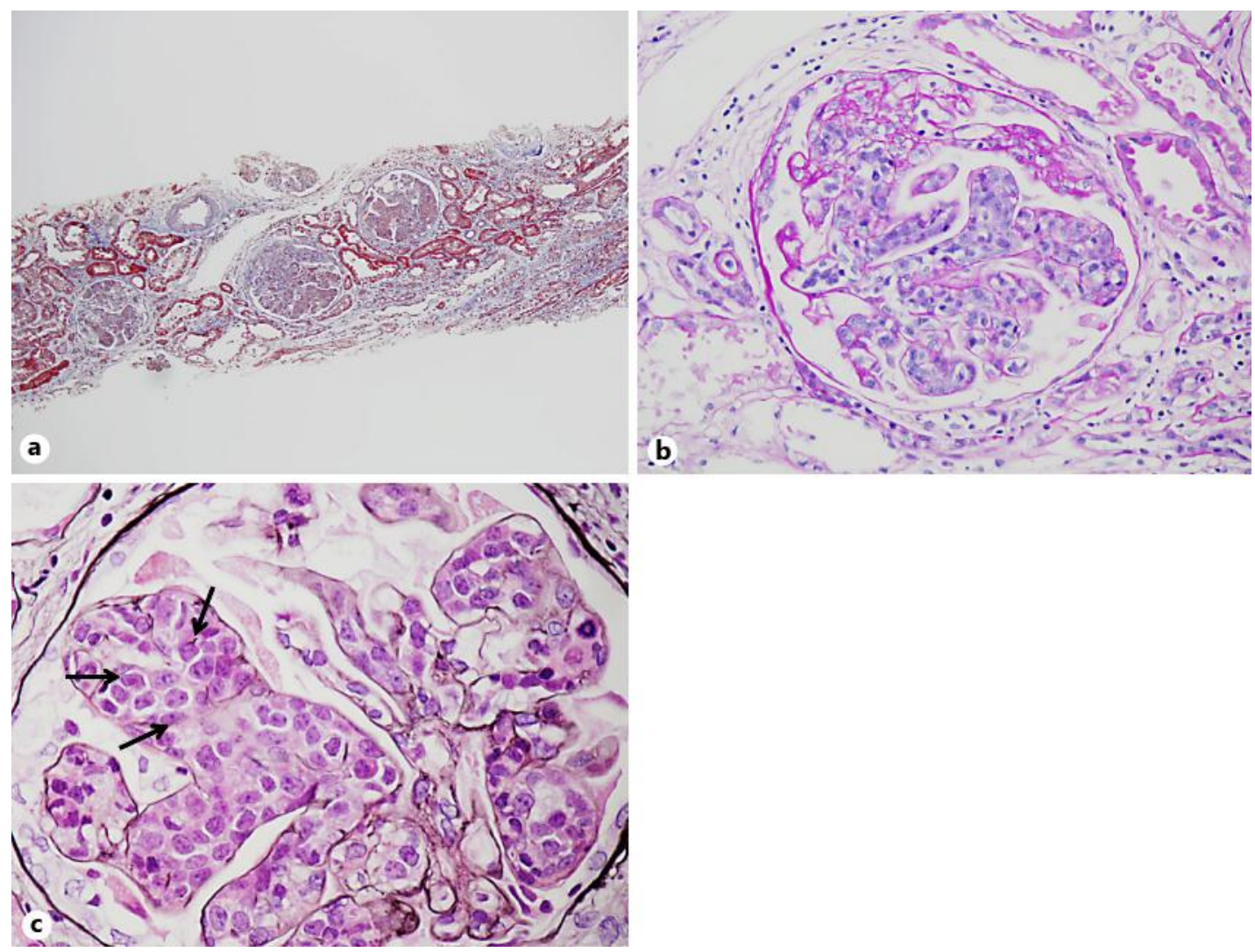

Fig. 2. Light microscopy of the renal biopsy specimen, which contained 12 glomeruli, with 2 showing global sclerosis. a There was mild fibrosis and atrophy and very slight cellular infiltration in the tubulointerstitial region (Masson trichrome stain). b Six of the 12 glomeruli were enlarged (PAS stain). c Glomerular capillaries were filled with atypical large cells that had atypical nucleoi (arrows; PAM stain). 


\section{Case Reports in \\ Nephrology and Dialysis}

\begin{tabular}{l|l}
\hline \multicolumn{2}{l}{ Case Rep Nephrol Dial 2015;5:173-179 } \\
\hline DOI: 10.1159/000437296 & $\begin{array}{l}\text { ○ 2015 S. Karger AG, Basel } \\
\text { www.karger.com/cnd }\end{array}$ \\
\hline
\end{tabular}

Hasegawa et al.: Characteristics of Intravascular Large B-Cell Lymphoma Limited to the Glomerular Capillaries: A Case Report

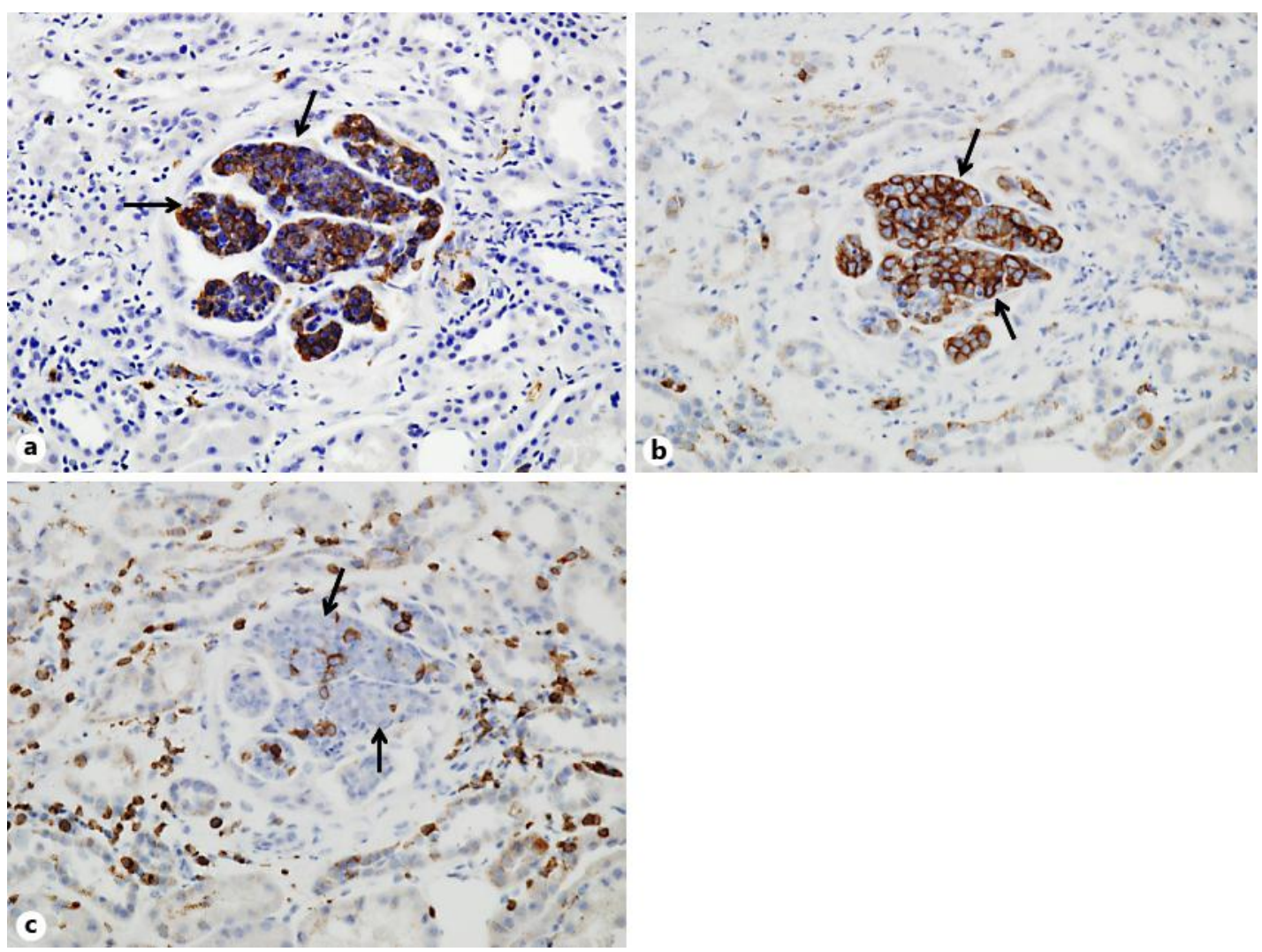

Fig. 3. Immunohistochemical staining. Atypical large lymphoid cells inside glomerular capillaries showed positivity for CD20 (arrows; a) and CD79a (arrows; b), but were negative for CD3 (arrows; c).

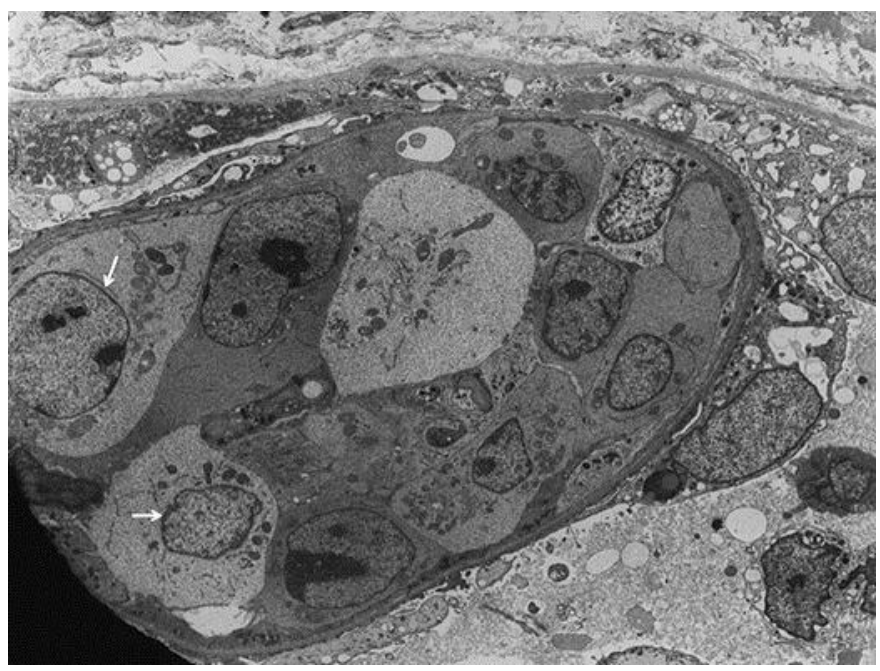

Fig. 4. Electron microscopy showed an increase in atypical cells with large nuclei (arrows), large nucleoli, masses of chromatin in the outer nuclear zone, and abundant endoplasmic reticulum in the cytoplasm. 